\title{
Genetic Variability on Grain Yield and Related Agronomic Traits of Faba Bean (Vicia faba L.) Genotypes Under Soil Acidity Stress in the Central Highlands of Ethiopia
}

\author{
Mesfin Tadele ${ }^{1,2, ~ *}$, Wassu Mohammed ${ }^{2}$, Mussa Jarso ${ }^{1}$ \\ ${ }^{1}$ Holetta Agricultural Research Center, Ethiopian Institute of Agricultural Research, Holetta, Ethiopia \\ ${ }^{2}$ School of Plant Sciences, College of Agriculture and Environmental Sciences, Haramaya University, Haramaya, Ethiopia
}

Email address:

mesfintadele64@gmail.com (M. Tadele)

${ }^{*}$ Corresponding author

To cite this article:

Mesfin Tadele, Wassu Mohammed, Mussa Jarso. Genetic Variability on Grain Yield and Related Agronomic Traits of Faba Bean (Vicia faba

L.) Genotypes Under Soil Acidity Stress in the Central Highlands of Ethiopia. Chemical and Biomolecular Engineering.

Vol. 4, No. 4, 2019, pp. 52-58. doi: 10.11648/j.cbe.20190404.12

Received: July 19, 2019; Accepted: October 31, 2019; Published: January 4, 2020

\begin{abstract}
Faba bean is the leading in area coverage and total production of pulses in Ethiopia. However, soil acidity becomes the major production limiting factor of faba bean in the highlands of Ethiopia. Information on genetic variability and heritability of faba bean genotypes on different traits under soil acidity stress is scanty. Thus, this study was conducted to estimate genetic variability of faba bean genotypes on grain yield and related traits at soil of pH 4.66, 4.96 and 4.49 at Holetta, Watebecha Minjaro and Jeldu, respectively, during 2017 main cropping season. The experiment comprised 50 faba bean genotypes arranged in randomized complete block design with three replications. Data were collected on grain yield $(\mathrm{g} / 5 \mathrm{plants})$ and some other agronomic traits: days to $50 \%$ flowering, days to $90 \%$ maturity, grain filling period, plant height (cm), number of poding nodes/plant, number of pods/ poding node, number of pods/plant, chocolate spot disease (\%) and 100-seeds weight (g). Analysis of variance for traits studied showed significant differences among genotypes, locations and their interaction $(\mathrm{P} \leq$ 0.01 ) for all traits except number of pods/poding node for the interaction. Computed genotypic (GCV) and phenotypic coefficient of variation (PCV) values were ranged from $1.08-23.05$ and $1.20-23.26 \%$, respectively, whereas heritability $\left(\mathrm{H}^{2}\right)$ and genetic advance as percent of the mean (GAM) ranged from $24.63-98.22 \%$ and $2.0-47.13 \%$, respectively. The highest values for all components were recorded for 100 -seeds weight while lowest values except for $\mathrm{H}^{2}$ computed for days to $90 \%$ maturity. The observed PCV and GCV values were high for 100 -seed weight and moderate for grain yield, number of poding node/plant and pod/plant. The values of PCV were higher than GCV for all traits. Hence, the high variation between PCV and GCV (6.78) for chocolate spot was due to environmental stress (soil acidity) besides the genetic constitution of tested genotypes. High $\mathrm{H}^{2}$ and GAM were observed for 100 -seeds weight, number of pod/plant and poding node/plant. Traits with high $\mathrm{H}^{2}$ indicated that selection based on mean would be successful in improving the traits. Therefore, selection based on phenotypic performance of genotypes would be effective to improve traits that have high GAM coupled with high $\mathrm{H}^{2}$ estimates.
\end{abstract}

Keywords: Faba Bean, Genetic Advance, Grain Yield, Heritability, Soil Acidity, Variability

\section{Introduction}

Faba bean (Vicia faba L., $2 \mathrm{n}=2 \mathrm{x}=12$ ) is produced throughout the world in different agro-ecological regions in which China followed by Ethiopia, Australia, United Kingdom, France and Egypt are the leading producers [1]. It is the leading pulse crops in Ethiopia [2]. It accounted for about 0.44 million ha $(27.34 \%)$ and about 0.92 million tons
$(30.95 \%)$ of the total pulse crops production. Oromia followed by Amhara Regional States are the largest producers of faba bean together accounting for about $83.20 \%$ of the country's production [3].

Faba bean has a potential to a good meat substitute in many parts of the world where there is demand for nonanimal protein sources [4]. It is also used as animal feed in industrialized countries and source of cash to the farmers and 
foreign currency to Ethiopia [5]. The crop is widely used in rotation with cereals because it fixes atmospheric nitrogen [5, $6,7]$. As a result, yield of cereal crops following faba bean is improved and it reduce the amount of artificial nitrogen fertilizer applications for subsistence farmers [8]. Despite its diverse benefits, the national average yield of faba bean (2.11 $\mathrm{t} \mathrm{ha}^{-1}$ ) in Ethiopia has remained low compared to Egypt and United Kingdom 3.47 and $3.83 \mathrm{t} \mathrm{ha}^{-1}$, respectively [1]. The low average yield of the crop is attributed to susceptibility to biotic and abiotic stresses [6]. Soil acidity is among the major production limiting factors for this crop in the high lands of Ethiopia [7, 9, 10]. Therefore, utilization of soil acidity tolerant genotypes is an important strategy in improving bean yields and reducing cost of production [11]. As a result, the use of acid tolerant varieties remains the first option and low cost if the use of lime is beyond the reach of smallholder farmers. However, so far 34 faba bean varieties have been released nationally in Ethiopia [7] but none of them were not tested and recommended for areas with soil acidity stress.

The knowledge of phenotypic (PCV) and genotypic (GCV) coefficients of variation helps to determine the type of breeding strategy to be followed [12]. The close correspondence between the GCV and PCV variation in faba bean has been reported that variability due to the genetic constitution of the genotypes was more than variability exerted by environmental factors [13, 14]. The high phenotypic and genotypic coefficients of variation is an indication of the less influence of environmental factors in the expression of traits and the higher chance to improve the traits through selection breeding [15]. It was reported high environmental variance than genotypic variance for days to $90 \%$ maturity and plant height [16]. Similarly, high phenotypic variance reported for days to $50 \%$ flowering, days to $90 \%$ maturity and plant height [17]. Likewise, high phenotypic variance reported for days to $50 \%$ flowering and plant height [14]. The magnitude of broad sense heritability $\left(\mathrm{H}^{2}\right)$ also helps in predicting the behavior of succeeding generations by devising the appropriate selection criteria and assessing the level of genetic improvement [12]. High estimates of $\mathrm{H}^{2}$ reported for 100 -seed weight and grain yield in faba bean genotypes at varied environments and number of genotypes [14, 18-20]. Also, high heritability reported for chocolate spot disease [21]. Thus, traits with high to moderate heritability may respond moderate to high for phenotypic selection [22]. The genetic gain expected from selection of the top $5 \%$ of the genotypes, as a percent of the mean (GAM) indicates the genetic progress that can be made in the breeding program [12]. High GAM was reported in faba bean for number of pods per plant $[18,20]$. Low GAM was reported for 100-seed weight and grain yield [14].

Variability and heritability of faba bean genotypes for grain yield and other morpho-agronomic traits under soil acidity is scanty. Therefore, genetic variability and estimating $\mathrm{H}^{2}$ of traits is of paramount importance for breeders because the genetic advance achieved in each breeding cycle depends on how the additive gene effect is beneficial. Hence, this study was conducted to estimate genetic variability under soil acidity stress on grain yield and related traits of faba bean genotypes.

\section{Materials and Methods}

The experiment was conducted at three locations Holetta, Watabecha Minjaro and Jeldu during 2017 main cropping season under rain fed condition. Descriptions of the experimental sites have been given in Table 1 below.

Table 1. Description of the study sites.

\begin{tabular}{|c|c|c|c|c|c|c|}
\hline \multirow{2}{*}{ Location } & \multirow{2}{*}{$\begin{array}{l}\text { Latitude and } \\
\text { longitude }\end{array}$} & \multirow{2}{*}{ Altitude (masl) } & \multirow{2}{*}{$\begin{array}{l}\text { Annual rain fall } \\
(\mathrm{mm})\end{array}$} & \multicolumn{2}{|c|}{ Temperature $\left({ }^{\circ} \mathrm{C}\right)$} & \multirow{2}{*}{ Soil pH } \\
\hline & & & & Min & Max & \\
\hline Holetta & $09^{0} 00^{\prime} \mathrm{N}, 38^{0} 30^{\prime} \mathrm{E}$ & 2400 & 1072 & 6.6 & 24.1 & 4.66 \\
\hline Watebecha Minjaro & $09^{0} 05^{\prime} \mathrm{N}, 38^{0} 36^{\prime} \mathrm{E}$ & 2565 & 1100 & 8.7 & 23.3 & 4.94 \\
\hline Jeldu & $09^{0} 16^{\prime} \mathrm{N}, 38^{0} 05^{\prime} \mathrm{E}$ & 2800 & 1200 & 2.06 & 16.9 & 4.49 \\
\hline
\end{tabular}

\subsection{Treatment and Experimental Design}

A total of 50 faba bean genotypes were used of which 22 were released varieties and 28 pipeline genotypes. The materials were collected from Holetta agricultural research center (Table 2). The experiment was arranged in Randomized Complete Block Design with three replications. The spacing between blocks was $1.5 \mathrm{~m}$. The experimental plots consisted of one row of $4 \mathrm{~m}$ length and $0.4 \mathrm{~m}$ row spacing continuously and
$0.1 \mathrm{~m}$ between plants. Undamaged clean seeds of each genotype were selected to a reasonably uniform size by hand sorting and whole set of genotypes were planted at each block. Blended Fertilizer was applied at the rate of $19 \mathrm{~kg} \mathrm{~N}, 38 \mathrm{~kg}$ $\mathrm{P}_{2} \mathrm{O}_{5}$ and $7 \mathrm{SO}_{4}$ in the form of NPS $121 \mathrm{~kg} / \mathrm{ha}$ that can substitute DAP in each area during planting. One faba bean variety (Dosha) was planted as a border row in each block to avoid border effect. Weeding and other cultural practices were done as per the national recommendations of the crop.

Table 2. Description of experimental materials.

\begin{tabular}{|c|c|c|c|c|c|c|c|}
\hline No. & Genotypes & Year of release & Origin & No. & Genotypes & Year of release & Origin \\
\hline 1 & Cool-0030 & --- - & Collection & 26 & EKLS/CSR02017-3-4 & 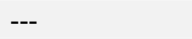 & Hybridization \\
\hline 2 & Wolki & 2008 & Hybridization & 27 & Kasa & 1980 & Collection \\
\hline 3 & EKLS/CSR02012-2-3 & --- & Hybridization & 28 & Cool-0025 & --- & Collection \\
\hline 4 & Obse & 2007 & Hybridization & 29 & EH06070-3 & --- & Hybridization \\
\hline 5 & NC58 & 1978 & Collection & 30 & EKLS/CSR02010-4-3 & --- & Hybridization \\
\hline
\end{tabular}




\begin{tabular}{|c|c|c|c|c|c|c|c|}
\hline No. & Genotypes & Year of release & Origin & No. & Genotypes & Year of release & Origin \\
\hline 6 & Ashebeka & 2015 & Hybridization & 31 & Cool-0031 & 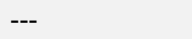 & Collection \\
\hline 7 & Hachalu & 2010 & Hybridization & 32 & Cool-0018 & --- & Collection \\
\hline 8 & Degaga & 2002 & Introduction & 33 & EKLS/CSR02028-1-1 & --- & Hybridization \\
\hline 9 & EH09031-4 & --- & Hybridization & 34 & EK 05037-4 & --- & Hybridization \\
\hline 10 & Holetta-2 & 2001 & Introduction & 35 & Cool-0035 & --- & Collection \\
\hline 11 & EH09007-4 & --- & Hybridization & 36 & KUSE2-27-33 & 1979 & Introduction \\
\hline 12 & EH07023-3 & --- & Hybridization & 37 & EH07015-7 & --- & Hybridization \\
\hline 13 & EK05006-3 & --- & Hybridization & 38 & Cool-0024 & --- & Collection \\
\hline 14 & EKLS/CSR02014-2-4 & --- & Hybridization & 39 & Selale & 2002 & Collection \\
\hline 15 & Numan & 2016 & Hybridization & 40 & Moti & 2006 & Hybridization \\
\hline 16 & Bulga 70 & 1994 & Collection & 41 & ЕH06027-2 & --- & Hybridization \\
\hline 17 & EK05001-1 & --- & Hybridization & 42 & EKLS/CSR02019-2-4 & --- & Hybridization \\
\hline 18 & Dosha & 2008 & Collection & 43 & EH09002-1 & --- & Hybridization \\
\hline 19 & Gora & 2012 & Hybridization & 44 & Tumsa & 2010 & Hybridization \\
\hline 21 & Wayu & 2002 & Collection & 46 & EK05037-5 & --- & Hybridization \\
\hline 22 & EKLS/CSR02023-2-1 & --- & Hybridization & 47 & Didi’a & 2014 & Hybridization \\
\hline 23 & Mesay & 1995 & Hybridization & 48 & Cool-0034 & --- & Collection \\
\hline 24 & EH09004-2 & --- & Hybridization & 49 & CS20DK & 1977 & Collection \\
\hline 25 & ЕH06088-6 & --- & Hybridization & 50 & Tesfa & 1995 & Introduction \\
\hline
\end{tabular}

“---” pipeline genotypes

\subsection{Data Collection}

The following data were collected either from whole plot or from five sample plants from each plot. Mean values of these samples were utilized to estimate the efficiency of each genotype for the traits under consideration. The traits days to $50 \%$ flowering, days to $90 \%$ physiological maturity, grain filling period, 100- seeds weight, chocolate spot disease, plant height, number of poding nodes/plant, number of pods/plant, number of pod/poding node and grain yield were considered under this investigation.

\subsection{Data Analysis}

\subsubsection{Homogeneity Test}

Before proceeding with the analysis of variance for each variable, tests were made for homogeneity of error variance using the F-max method which is based on the ratio of the larger mean square of error (MSE) from the separate analysis of variance to the smaller mean square of error [23].

$$
\mathrm{F}-\text { ratio }=\frac{\text { Larger MSE }}{\text { Smaller MSE }}
$$

\subsubsection{Analysis of Variance}

The data were subjected to analyses of variance and combined analysis of variance over environments for randomized complete block design was performed using the SAS program [24]. The total variability for the traits was quantified using pooled analyses of variance over three locations using the following model:

$$
\mathrm{P}_{\mathrm{ijk}}=\mu+\mathrm{B}_{\mathrm{i}}\left(\mathrm{L}_{\mathrm{k}}\right)+\mathrm{G}_{\mathrm{j}}+\mathrm{L}_{\mathrm{k}}+(\mathrm{GL})_{\mathrm{jk}}+\mathrm{e}_{\mathrm{ijk}}
$$

Where $P_{i j k}=$ phenotypic observation on genotype $\mathrm{j}$ in block i (at location k) G, B, and $\mathrm{L}=$ number of genotypes, blocks and locations respectively, $\mu=$ grand mean, $\mathrm{B}_{\mathrm{i}}\left(\mathrm{L}_{\mathrm{k}}\right)=$ the effect of block $\mathrm{i}$ (within location $\mathrm{k}$ ), $\mathrm{G}_{\mathrm{j}}=$ the effect of genotype $\mathrm{j}, \mathrm{L}_{\mathrm{k}}=$ the effect of location $\mathrm{k},(\mathrm{GL})_{\mathrm{jk}}=$ the interaction effect between genotype $\mathrm{j}$ and location $\mathrm{k}$ and $\mathrm{e}_{\mathrm{ijk}}=$ effects of random error.

\subsubsection{Variance Components}

The coefficients of variations at phenotypic and genotypic levels were estimated using the adopted formula [25]. The PCV and GCV values were categorized as low for values ranged from $0-10 \%$, moderate $10-20 \%$ and high for values greater than $20 \%$.

$$
\begin{aligned}
& \mathrm{PCV}=\frac{\sqrt{\text { phenotypic variance }}}{\text { Grand mean }} \times 100 \\
& \mathrm{GCV}=\frac{\sqrt{\text { Genotypic Variance }}}{\text { Grand mean }} \times 100
\end{aligned}
$$

Broad-sense heritability $\left(\mathrm{H}^{2}\right)$ was estimated for pooled analysis over three locations using the formula adopted by Allard [12].

$$
\mathrm{H}^{2}=\sigma \mathrm{g}^{2} /\left[\sigma \mathrm{g}^{2}+\sigma \mathrm{gl}^{2} / \mathrm{L}+\sigma \mathrm{e}^{2} / \mathrm{RL}\right] \times 100
$$

Where: $\mathrm{H}^{2}=$ heritability in broad sense, $\sigma^{2} \mathrm{~g}=$ genotypic variance, $\sigma \mathrm{gl}^{2}=$ genotype by location interaction effects, $\sigma^{2} \mathrm{e}$ $=$ error variance, $\mathrm{R}=$ number of replication and $\mathrm{L}=$ number of location.

Genetic advance in absolute unit (GA) and percent of the mean (GAM), was estimated in accordance with the methods illustrated [25]. Genetic advance that is expected from selecting the top $5 \%$ of the tested genotypes as percentage of the mean (GAM) was categorized as low (0-10), moderate $(10-20)$ and high $(>20)$.

$$
\mathrm{GA}=\mathrm{k} \cdot \sigma \mathrm{p} \cdot \mathrm{h}^{2} \text { and } \mathrm{GA}(\text { as } \% \text { of the mean })=\frac{G A}{\overline{\mathrm{x}}} \times 100
$$

Where, $\mathrm{k}=$ selection differential (at $5 \%$ selection intensity with value 2.06$) \sigma p=$ phenotypic standard $h^{2}=$ heritability; $\overline{\mathrm{x}}=$ Grand mean. 


\section{Results and Discussion}

\subsection{Analysis of Variance}

Mean squares due to locations were highly significant $(\mathrm{P}<0.01)$ for all traits under consideration, indicating that there are differences between the three environments which are significant enough to see the genetic performance of faba bean genotypes. Also, it is evident from the results that mean squares due to genotypes (572.51) were highly significant for grain yield, indicating the existence of enough genetic variability for grain yield. The two-way interaction (genotype $\mathrm{x}$ location) had significant effects on all 10 traits except number of pods per poding node (Table 3 ). The effect of $\mathrm{G} \mathrm{x}$ $\mathrm{L}$ being significant on most of the traits over location indicated the differential performance of genotypes in different locations. Inline with this result it was reported significant genotypic differences in faba bean genotypes for days to flowering, plant height, number of pod/plant and hundred seed weight [26]. Significant effect of locations on 100-seed weight of faba bean has been reported [27]. Many reports also showed the presence of significant effects of $G \mathrm{x}$ $\mathrm{L}$ interaction on grain yield in faba bean in different sets of environments in Ethiopia $[18,28]$. Contrary to the current result, non-significant interaction effect of chocolate spot disease due to environmental variance was observed [28].

The significant effects of $\mathrm{G} \times \mathrm{L}$ interaction indicated that the genotypes had differential performance over locations for agronomic traits. Due to performance inconsistency of genotypes over locations such as with significant effects of $G$ $\mathrm{x} L$, selection of genotypes for superior efficiency under one set of environments may not perform consistently under different environment. This implies that recommendation of genotypes for all locations is hardly possible based on better performance of genotypes at one location. Likewise, it was reported that, under significant $\mathrm{G} \times \mathrm{L}$ selection of genotypes that perform best under all sets of environments becomes impractical [29].

Table 3. Mean squares for 10 traits of 50 faba bean genotypes evaluated over three locations in 2017 cropping season.

\begin{tabular}{|c|c|c|c|c|c|c|}
\hline Trait & $\operatorname{Rep}(d . f=6)$ & Genotype (G) (d.f =49) & Location (L) (d.f =2) & $G \times L(d . f=98)$ & Error $(d . f=294)$ & CV (\%) \\
\hline $\mathrm{DF}$ & 11.54 & $22.67^{* *}$ & $4730.67^{* *}$ & $4.45^{* *}$ & 1.22 & 2.05 \\
\hline DM & 20.56 & $27.38^{* *}$ & $4012.56^{* *}$ & $5.20^{* *}$ & 2.69 & 1.12 \\
\hline GFP (day) & 28.59 & $37.51^{* *}$ & $4401.98^{* *}$ & $8.22^{* *}$ & 3.69 & 2.09 \\
\hline PNP & 8.19 & $5.90^{* *}$ & $242.89^{* *}$ & $1.20^{* *}$ & 0.78 & 13.49 \\
\hline $\mathrm{PP}$ & 4.62 & $21.55^{* *}$ & $309.31^{* *}$ & $2.86^{* *}$ & 1.52 & 14.75 \\
\hline PPN & 0.11 & $0.09^{* *}$ & $0.13^{* *}$ & 0.02 & 0.02 & 11.16 \\
\hline $\mathrm{CS}(\%)$ & 1451.75 & $482.59^{* *}$ & $2502.76^{* *}$ & $344.07^{* *}$ & 143.28 & 36.29 \\
\hline GY (g) & 430.05 & $572.51^{* *}$ & $15788.37^{* *}$ & $190.83^{* *}$ & 58.96 & 12.20 \\
\hline
\end{tabular}

*, ** significant at $\mathrm{P} \leq 0.05$ and $\mathrm{P} \leq 0.01$, respectively, Rep $=$ replication, $\mathrm{CV}(\%)=$ coefficient of variation in percent, $\mathrm{DF}=$ days to $50 \%$ flowering, $\mathrm{DM}=$ days to $90 \%$ maturity, GFP = Grain filling period, PH = plant height, PNP = Number of poding node/plant, PP = Number of Pod/Plant, PPN = Number of $\mathrm{pod} /$ poding node, $\mathrm{HSW}=100$-seed weight, $\mathrm{CS}=$ Chocolate spot disease $(\%)$ and $\mathrm{GY}=$ Grain yield $(\mathrm{g} / 5 \mathrm{plants})$.

\subsection{Estimates of Phenotypic and Genotypic Coefficient of Variation}

The values of genotypic (GCV) and phenotypic (PCV) coefficients of variations for agro-morphology traits fall in the range between 1.08 and 23.05 and between 1.20 and $23.26 \%$, respectively. The lowest and highest values of GCV and PCV were calculated for days to $90 \%$ maturity and 100 seed weight, respectively. The differences between PCV and GCV values were in the range between $0.12-6.78$ for days to $90 \%$ maturity and chocolate spot disease, respectively (Table 4). The high variation between PCV and GCV for chocolate spot was because of environmental stress. Similarly, narrow PCV and GCV variation in faba bean have been reported by various authors and they stated that variability due to the genetic constitution of the genotypes was more than variability exerted by environmental factors [13, 14]. However, traits like chocolate spot that have high PCV values than GCV implies greater influence of environmental factors for the phenotypic expression of these traits that make difficult or practically impossible to exercise selection based on phenotypic performance of the genotypes to improve the traits.

The PCV and GCV values were high for 100-seed weight moderate for number of poding node/plant, number of pod/plant and grain yield. The high to moderate PCV and GCV for the mentioned traits suggested that the traits were less influenced by environmental factors and selection based on phenotypic expression of the genotypes could be applied as breeding method. Likewise, it was reported that, high PCV and GCV values were an indication of the less influence of environmental factors in the expression of traits and the higher chance to improve the traits through selection breeding [15]. The PCV values were moderate and GCV values were low $(<10 \%)$ for chocolate spot and the values were low for both parameters for days to $50 \%$ flowering, days to $90 \%$ maturity, plant height and grain filling period (Table 4). This implies greater influence of environmental factors for the phenotypic expression of these traits that make difficult or practically impossible to exercise selection based on phenotypic performance of the genotypes to improve the traits. In close agreement with this result, high environmental variance than genotypic variance were reported for days to $90 \%$ maturity and plant height [16]. Likewise, high environmental variance reported for days to $50 \%$ flowering 
and plant height $[14,17]$.

Table 4. Estimates of phenotypic and genotypic coefficient of variation, heritability and genetic advance for 9 traits of 50 faba bean genotypes based on the analysis of variance over three locations in 2017 cropping season.

\begin{tabular}{llllllllll}
\hline Traits & Range & Mean & $\boldsymbol{\sigma}^{\mathbf{2}}$ & $\boldsymbol{\sigma}^{\mathbf{2}} \mathbf{p h}$ & $\mathbf{G C V}$ & $\mathbf{P C V}$ & $\mathbf{H}^{\mathbf{2}}$ & $\mathbf{G A ~ K = 5 \%}$ & $\mathbf{G A M}$ \\
\hline DF & $51.44-58.89$ & 54.06 & 2.02 & 2.52 & 2.63 & 2.94 & 80.37 & 2.63 & 4.87 \\
DM & $142.11-149.00$ & 145.86 & 2.46 & 3.04 & 1.08 & 1.20 & 81.01 & 2.91 & 2.00 \\
GFP & $87.22-95.33$ & 91.80 & 3.26 & 4.17 & 1.97 & 2.22 & 78.10 & 3.29 & 3.58 \\
PH & $100.78-119.00$ & 111.24 & 10.63 & 19.45 & 2.93 & 3.96 & 54.68 & 4.97 & 4.47 \\
PNP & $5.11-8.33$ & 6.54 & 0.52 & 0.66 & 11.06 & 12.38 & 79.74 & 1.33 & 20.37 \\
PP & $5.56-12.67$ & 8.36 & 2.08 & 2.39 & 17.24 & 18.52 & 86.71 & 2.77 & 33.12 \\
HSW & $35.39-93.92$ & 70.13 & 261.42 & 266.17 & 23.05 & 23.26 & 98.22 & 33.06 & 47.13 \\
GY & $40.72-79.56$ & 62.93 & 42.41 & 63.61 & 10.35 & 12.67 & 66.67 & 10.97 & 17.43 \\
CS & $26.17-43.69$ & 34.39 & 5.27 & 21.41 & 6.68 & 13.46 & 24.63 & 2.35 & 6.84 \\
\hline
\end{tabular}

$\sigma^{2} \mathrm{~g}=$ Genotypic variance, $\sigma^{2} \mathrm{p}=$ phenotypic variance, $\mathrm{GCV}=$ Genotypic coefficient of variation, $\mathrm{PCV}=$ phenotypic coefficient of variation, $\mathrm{H}^{2}=$ broad sense heritability, $\mathrm{GA}=$ Genetic advance, $\mathrm{GAM}=$ Genetic advance as percentage of mean, $\mathrm{DF}=$ days to $50 \%$ flowering, $\mathrm{DM}=$ days to $90 \% \mathrm{maturity}$, GFP $=\mathrm{Grain}$ filling period, $\mathrm{PH}=$ plant height, $\mathrm{PNP}=$ Number of poding node/plant, $\mathrm{PP}=$ Number of Pod/Plant, HSW = 100-seed weight, $\mathrm{CS}=\mathrm{Chocolate}$ spot disease $(\%)$ and $\mathrm{GY}=$ Grain yield $(\mathrm{g} / 5$ plants)

\subsection{Estimates of Heritability and Expected Genetic Advance}

The broad sense heritability $\left(\mathrm{H}^{2}\right)$ and genetic advance as percent of mean (GAM) values ranged from 24.63 to $98.22 \%$ and 2.0 to $47.13 \%$, respectively, over locations. Heritability values can be categorized as low $(<30 \%)$, moderate $(30-60 \%)$ and high $(>60 \%)$ and genetic advance as percent of mean classified as low $(<10 \%)$, moderate $(10-20 \%)$ and high $(>20 \%)$ [25]. Hence, low and high heritability values were calculated for chocolate spot disease and 100-seed weight, respectively. Also, low and high GAM computed for days to $90 \%$ maturity and 100- seed weight, respectively (Table 4). In contrary to the current result, it was reported high GAM for seed yield (35.46\%) [18].

It was suggested that the importance of considering both the genetic advance and heritability of traits rather than considering separately in determining how much progress can be made through selection [25]. In this study, high heritability accompanied with high to moderate genetic advance was observed for number of poding node/plant, number of pod/plant, 100-seed weight and grain yield. This indicated that these traits were highly heritable and selection of high performing genotypes is possible to the improvement of the traits. Therefore, selection based on phenotypic performance of genotypes would be effective to improve traits that have high genetic advance as percent of mean coupled with high heritability estimates. The traits with high to moderate heritability, indicates that it may respond moderate to high for phenotypic selection [22]. The high $\mathrm{H}^{2}$ and GAM value of traits indicates the high possibility of transferring traits from parents to the next progeny. In agreement with this result, high estimates of broad sense heritability for 100 -seed weight and grain yield in faba bean genotypes were reported at varied environments and number of genotypes $[14,18,19]$. Likewise, high GAM was reported for number of pod/plant $[18,20]$. In contradict to this finding low GAM reported for 100-seed weight and grain yield [14]. Low GAM values were calculated for chocolate spot. Low heritability coupled with low GAM was calculated for chocolate spot (Table 4). The result indicated that low heritability values for chocolate spot limit possibility of improvement for this trait through selection. In contradict to this result it was reported high $\mathrm{H}^{2}$ for chocolate spot disease [21].

Generally, 100-seed weight had high PCV, GCV, $\mathrm{H}^{2}$ and GAM values which indicated that this trait is controlled by genetic factor and higher chance to improve this trait through selection. The probable reason for the variation of traits low to high GAM and vice versa with this result and others were due to the difference of growing environments and genetic makeup of the evaluated genotypes. Thus, under stressed environments $\mathrm{H}^{2}$ and GAM values may be masked due to a greater genotype by environment interaction [30]. In contrary, $\mathrm{H}^{2}$ and GAM values influenced by the nature of the genetic material evaluated rather than the growing environment [31].

\section{Conclusion}

Faba bean is an important legume crop in Ethiopia mainly cultivated in the mid to high altitude areas with elevations 1800-3000 meter above sea level. The crop is a major source of protein for highland inhabitants those who cannot afford animal products and restores soil fertility. However, the highlands of Ethiopia are characterized by high soil acidity which becomes the major production constraints of faba bean The mean squares due to genotypes showed the presence of significant $(\mathrm{P}<0.01)$ differences for all agronomic traits. Similarly, the mean squares due to $\mathrm{G} \times \mathrm{L}$ were significant for all traits except number of pod/poding node. The results indicated the presence of genetic variability in faba bean genotypes for most of agro-morphology traits that could be exploited in breeding programs. The significant differences among locations, G x L interactions on grain yield and other traits showed the differential response of genotypes over locations and the test locations were different each other.

The computed GCV values ranged from 1.08-23.05 and PCV between $1.20-23.26 \%$ whereas $\mathrm{H}^{2}$ ranged from $63-$ $98.22 \%$ and GAM from $2.0-47.13 \%$. The highest values for all components obtained for 100 -seeds weight while all 
lowest values except for $\mathrm{H}^{2}$ obtained for days to $90 \%$ maturity. Medium to high estimates of GCV, PCV, $\mathrm{H}^{2}$ and GAM computed for 100- seeds weight and number of pod/plant suggested selection based on phenotypic expression of genotypes is possible to improve the traits. However, traits with high PCV values than GCV the $\mathrm{H}^{2}$ and GAM values will be low due high environmental factors which limit improvements of these traits. The high PCV values than GCV for all traits were because of environmental variation attributed by soil acidity. Therefore, the results allows conclude that the presence of genetic variability among the evaluated faba genotypes is a good opportunity to identify genotypes of interest.

\section{Conflict of Interest}

All the authors do not have any possible conflicts of interest.

\section{Acknowledgments}

I wish to express my great appreciation to my major advisor Dr. Wassu Mohammed and co-advisor Dr. Mussa Jarso, for their professional support and guidance to complete this research.

I wish to express my sincere thanks and deepest gratitude to my staffs Dr. Gemechu Keneni and Dr. Asnakech Tekalign assistance and guidance. I am sincerely grateful to Adisu Tsegaye, Etetu Demisie and Asnakech Shikur for their remarkable support during data collection. I thank the soil laboratory staffs of Holetta Agricultural Research Center and Mr. Fekadu Mosisa for his unreserved support.

Finally, Great appreciation goes to Ethiopian Institute of Agricultural Research for allowing budget and Holetta Agricultural Research Center for providing resources to the research work.

\section{References}

[1] FAOSTAT (Food and Agriculture Organization Statistics). 2018. Statistical database of agricultural production. Rome, Italy.

[2] Alene, T. and Bezabih, A. 2012. Genotype x Environment interaction and stability analysis of faba bean (Vicia faba L.) varieties in North Ethiopia. Libyan Journal of International, 3 (4): 195-200.

[3] CSA (Central Statistical Agency of Ethiopia). 2017/18. Report on Area and Production of Major Crops (Private peasant holdings, meher season). Statistical Bulletin, Addis Ababa, Ethiopia, 1 (586): 10-29.

[4] Crépon, K., Marget, P., Peyronnet, C., Carrouée, B., Arese, P. and Duc, G. 2010. Nutritional value of faba bean (Vicia faba L.) seeds for feed and food. Field Crops Research, 115: 329-339.

[5] Tesfaye, T., Azanaw, A., Tilahun, G., mulat, K. and Sahile, S. 2015. Evaluation of faba bean (Vicia faba L.) varieties against chocolate spot (Botrytis fabae) in North Gondar, Ethiopia.
African Journal of Agricultural Research, 10 (30): 2984-2988.

[6] Keneni, G., Fikre, A. and Eshete, M. 2016. Reflections on Highland Pulses Improvement Research in Ethiopia. Ethiopian Journal of Agricultural Sciences, 1 (16): 17-50.

[7] Tadele, M. 2019. Breeding achievements of faba bean (Vicia $f a b a$ L.) and its impact in the livelihood of Ethiopian farmers. International Journal of Agriculture and Bioscicence 8 (5): 263-269.

[8] IFPRI (International Food Policy Research Institute). 2010. Fertilizer and Soil Fertility Potential in Ethiopia. Working Paper. Washington: IFPRI. Institute. UK.

[9] Jida, M. and Assefa, F. 2014. Effects of Acidity on Growth and Symbiotic Performance of Rhizobium leguminosarum $\mathrm{p} v$. viciae Strains Isolated from Faba Bean Producing Areas of Ethiopia. Science, Technology and Arts Reseasrch Journal, 3 (2): 26-33.

[10] Fekadu, E., Kibret K., Melese, A. and Bedadi, B. 2018. Yield of faba bean (Vicia faba L.) as affected by lime, mineral P, farmyard manure, compost and rhizobium in acid soil of lay gayint district, northwestern highlands of Ethiopia. Agriculture and Food Security, 7 (16): 1-11.

[11] Fageria, N. K., Baligar, V. C., Melo, L. C. and de Oliveira, J. P. 2012. Differential soil acidity tolerance of dry bean genotypes. Communications in Soil Science and Plant Analysis 43 (11): 1523-153

[12] Allard, R. W. 1960. Principle of Plant Breeding. John Wiley and Sons Inc. Publisher, New York, USA.

[13] Solieman, T. H. I. and Ragheb, E. I. M. 2014. Two selection methods and estimation of some important genetic parameters in broad bean (Vicia faba L.). Asian Journal of Crop Science, 6 (1): $38-48$.

[14] Hamza, F. E., Khalifa, G. E. and Ahmed, A. A. 2017. Assessment of genotypic and phenotypic variability, heritability and genetic advance for seed yield and related agronomic traits in faba bean (Vicia faba L.) genotypes in the Northern State, Sudan. Net Journal of Agricultural Science, 5 (2): 48-52.

[15] Ejara, E., Mohammed, W. and Amsalu, B. 2016. Genetic variability, heritability and expected genetic advance of yield and yield related traits in common bean genotypes (Phaseolus vulgaris L.) at Abaya and Yabello, Southern Ethiopia. African Journal of Biotechnology, 17 (31): 973-980.

[16] Haridy, M. H. and El-Said, M. A. A. 2016. Estimates of Genetic Parameters Using Populations in Faba Bean (Vicia faba L). Journal of Plant Production, Mansoura University, 7 (12): $1443-1447$.

[17] Sekhon B. S., Singh Y., Sharma S., Verma A., Sharma S. and Vishalakshi. 2017. Genetic Variability and Interrelationships of Yield and Yield Components in Faba Bean (Vicia faba L.). Indian Journal of Ecology, 44 (4): 877-882.

[18] Fikreselassie, M. and Seboka, H. 2012. Genetic variability on seed yield and related traits of elite faba bean (Vicia faba 1 .) genotypes. Pakistan Journal of Biological Sciences, 15 (8): 380-385.

[19] Mulualem T., Dessalegn, T. and Dessalegn, Y. 2013. Genetic variability, heritability and correlation in some faba bean genotypes (Vicia faba L.) grown in North. International Journal Genetics and Mololecular Biology 5 (1): 8-12. 
[20] Bakhiet, M. A., El-Said, R. A., Raslan, M. A, and Abdalla, N. G. 2015. Genetic variability, heritability and correlation in some faba bean genotypes under different sowing dates. World Applied Sciences Journal, 33 (8): 1315-1324.

[21] El-Badawy, N. F., Abo-Hegazy, S. R., Mazen, M. M. and ElMenem, H. A. 2012. Evaluation of some faba bean genotypes against chocolate spot disease using cDNA fragments of chitinase gene and some traditional methods. Asian Journal of Agricultural research, 6 (2): 60-72.

[22] Singh, M. and Ceccarelli, S. 1996. Estimation of heritability of crop traits from variety trial data. Technical Manual International Center for Agricultural Research in the Dry Areas, Aleppo, Syria.

[23] Gomez, K. A. and Gomez, A. 1984. Statistical Procedures for Agricultural Research, $2^{\text {nd }}$ Edition. John Wiley \& Sons, New York.

[24] SAS Institute. 2010. SAS/STAT guide for personal computers, version 9.3 edition. Cary, NC: SAS Institute Inc.

[25] Johnson, H. W., Robinson, H. F. and Comstock, R. F. 1955. Genotypic and Phenotypic correlation in soybean and their implication in selection. Agronomy Journal, 47: 477-483.

[26] Kumar, P., Das, R. R., Bishnoi, S. K. and Sharma, V. 2017. Inter-correlation and path analysis in faba bean (Vicia faba L.). Electronic Journal of Plant Breeding, 8 (1): 395-397.
[27] Mitiku, A. and Wolde, M. 2015. Effect of Faba Bean (Vicia faba L.) Varieties on Yield Attributes at Sinana and Agarfa Districts of Bale Zone, Southeastern Ethiopia. Jordan Journal of Biological Science, 4 (8): 281-286.

[28] Temesgen T., Keneni G. and Mohammad H. 2015. Genetic progresses from over three decades of faba bean (Vicia faba L.) breeding in Ethiopia. Australian Journal of Crop Science, 9 (1): 41-48.

[29] Keneni G., Bekele E., Assefa F., Imtiaz M., Debele T., Dagne K. and Getu E. 2015. Characterization of Ethiopian chickpea (Cicer arietinum L.) germplasm accessions for phosphorus uptake and use efficiency II. Interrelationships of characters and gains from selection. Ethiopian Journal of Applied Science and Technolology, 6 (2): 77-96.

[30] Ceccarelli, S. and Grando, S. 1996. Importance of specific adaptation in breeding for marginal conditions. pp 34-58, In: Gebre H. and Van Leur J. (Eds.). Barley research in Ethiopia: Past work and future prospects. Proc. 1st Barley Research Review Workshop, 16-19 Oct 1993, Addis Ababa: IAT/ICARDA. Addis Ababa, Ethiopia.

[31] Rosielle, A. and Hamblin, J. 1981. Theoretical aspects of selection for yield in stress and non-stress environments. Crop Science, 21: 943-946. 